\title{
Анизотропия свойств матрицы крупногабаритных углепластиков по толщине полуфабриката
}

\section{Anisotropy of the matrix properties of large-sized carbons on the thickness of the semi-finished product}

\section{Е. А. Вешкин, В. В. Семенычев,}

В. И. Постнов, Е. В. Крашенинникова

Ульяновский научно-технологический центр федерального государственного унитарного предприятия «Всероссийский научно-исследовательский институт авиационных материалов» (ФГУП «ВИАМ»)

\author{
E. A. Veshkin, V. V. Semenychev, \\ V. I. Postnov, E. V. Krasheninnikova \\ Ulyanovsk Science and Technology Centre \\ of the Federal State Unitary Enterprise \\ "All-Russian Scientific Research Institute \\ of Aviation Materials" (FSUE VIAM)
}

Поступила в редакцию 02.08.2021, принята к печати 29.09.2021

\section{Абстракт}

На образцах углепластиков переменного сечения толщиной до 16 мм проводили исследования по выявлению закономерностей изменения величин микротвёрдости в высотном сечении пластика. Измерения микротвёрдости матрицы углепластика проводили на поперечных шлифах в двух взаимно перпендикулярных плоскостях при нагрузке на индентор микротвердомера равной 10 грамм $(0,1 \mathrm{H})$. Проведёнными исследованиями установлено, что величина микротвёрдости матрицы углепластика по толщине от лицевой поверхности образца к его оборотной стороне изменяется по параболическому закону с максимальными значениями микротвёрдости в сердцевине сечения.

\section{Abstract}

On samples of carbon plastics of variable cross-section with a thickness of up to $16 \mathrm{~mm}$, studies were carried out to identify the regularities of changes in the values of microhardness in the height section of the plastic. Measurements of the microhardness of the CFRP matrix were carried out on transverse sections in two mutually perpendicular planes with a load on the microhardness tester indenter equal to 10 grams $(0.1 \mathrm{~N})$. The studies carried out have established that the value of the microhardness of the CFRP matrix along the thickness from the front surface of the sample to its reverse side changes according to the parabolic law with the maximum values of the microhardness in the core of the section

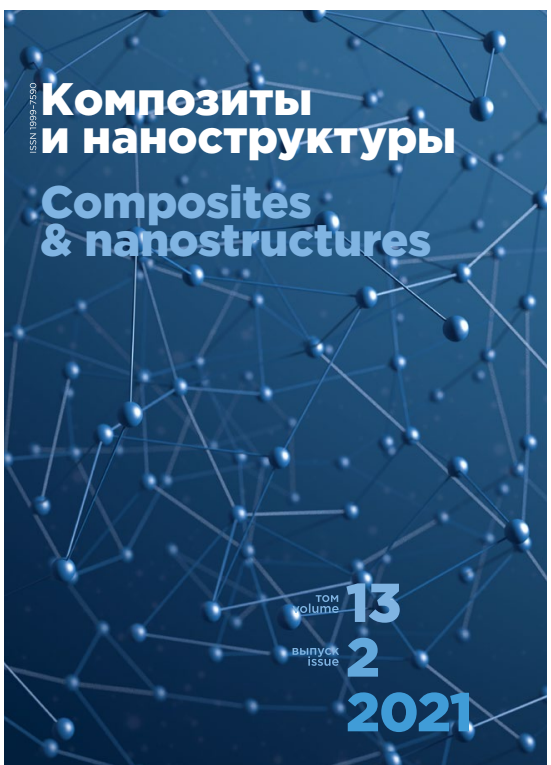

